\title{
COVID-19 - Infection prevention in prisons and jails in Poland
}

\author{
Anna Augustynowicz ${ }^{1,2, A, C-D \oplus}$, Michał Wójcik ${ }^{3, B, E} \oplus$, Beata Bachurska ${ }^{4, B, E-F} \oplus$, Janusz Opolski ${ }^{5, D-E \oplus}$, \\ Aleksandra Czerw ${ }^{1,6, E \oplus}$, Dorota Raczkiewicz ${ }^{2, C} \oplus$, Jarosław Pinkas ${ }^{2, E-F} \oplus$ \\ ${ }^{1}$ Medical University, Warsaw, Poland \\ ${ }^{2}$ School of Public Health, Centre of Postgraduate Medical Education, Warsaw, Poland \\ ${ }^{3}$ Faculty of Law and Administration, University of Silesia, Katowice, Poland \\ ${ }^{4}$ College of Social Sciences, Institute of Legal Studies, University of Rzeszów, Poland \\ ${ }^{5}$ Faculty of Engineering and Management, University of Ecology and Management, Warsaw, Poland \\ ${ }^{6}$ National Institute of Public Health - National Institute of Hygiene, Warsaw, Poland \\ A - Research concept and design, B - Collection and/or assembly of data, C - Data analysis and interpretation, \\ $D$ - Writing the article, E-Critical revision of the article, F-Final approval of the article
}

Augustynowicz A, Wójcik M, Bachurska B, Opolski J, Czerw A, Raczkiewicz D, Pinkas J. COVID-19 - Infection prevention in prisons and jails in Poland Ann Agric Environ Med. 2021; 28(4): 621-626. doi: 10.26444/aaem/140099

\begin{abstract}
Introduction and objective. Due to the specificity of conditions in penitentiary establishments, there is an increased risk of rapid spread of SARS-CoV-2 virus infections. In addition, there is a high prevalence of non-communicable chronic diseases among inmates, which increases the risk of the severe course of COVID-19. The objectives of the study are to present the number and percentage of officers and employees of the Prison Service (PS), and inmates quarantined and infected with the SARS-CoV-2 virus in the period from March to the end of December 2020, as well as to present solutions aimed at limiting the transmission of SARS-CoV-2 virus.

Materials and method. Information on the number of PS officers, employees and inmates quarantined and infected, as well as information on the solutions introduced by the Prison Service Management Bard,was obtained from the Ministry of Justice pursuant to the provisions of the Act on Access to Public Information.

Results. From1 March 2020 - 31 December 2020, the number of cases of infection detected among PS officers and employees was 3,666, and among inmates - 599. $97.7 \%$ of all cases among PS officers and employees and $93.8 \%$ among inmates were reported in the last 3 months of the year.

Conclusions. The rapid introduction of solutions aimed at limiting the transmission of the SARS-CoV-2 virus and proper monitoring of the epidemic in penitentiary establishments resulted in a low number of infections in the period from March to the end of December 2020. Infections among PS officers and employees, as well as inmates, seem to be parallel to the epidemiological situation in the population of the entire country. Further analysis of the epidemic will confirm the impact of the measures taken on the incidence of COVID-19 among PS officers, employees and inmates.
\end{abstract}

- Key words

SARS-CoV-2 virus, Covid-19, prisons

\section{INTRODUCTION}

At the beginning of the 2020, the world found out about the outbreak of a disease caused by a new coronavirus in Wuhan, China. On 31 January 2020, the Director-General of the World Health Organization (WHO) announced the State of Public Health Emergency of International Concern (PHEIC) [1] under the international health regulations.

Polish authorities monitored the epidemiological situation and, reacting on an ongoing basis, introduced legal provisions specifying administrative, budget and epidemiological instruments aimed at managing a possible epidemic caused by the SARS-CoV-2 virus. In addition to numerous amendments to the Act of 5 December 2008 on the prevention and combating of infections and infectious diseases in humans [2], aimed at adapting the provisions to the epidemiological situation, on 2 March 2020, the so-called Crisis Act was adopted, i.e. the Act on specific solutions

Address for correspondence: Anna Augustynowicz, Medical University, Warsaw, Poland

E-mail: aaugustynowicz@poczta.onet.pl

Received: 04.06.2021; accepted: 09.07.2021; first published: 22.07.2021 related to the preventing, counteracting and combating COVID-19, other infectious diseases, and the crisis situations caused by them (the provisions of this Act have been amended 17 times) [3]. Based on these laws, a number of restrictions and prohibitions have been introduced. One of the directions of the introduced changes was the regulation of special rules of conduct in relation to people particularly at risk of infection, e.g. in hospitals or long-term care facilities. This also applied to penitentiary establishments where virus outbreaks are difficult to control due to their population, varying access to hygiene facilities, and limited space for isolation and quarantine [4]. Penitentiary establishments are not fully closed systems, and they are not isolated from the outside world. As a consequence, the SARS-CoV-2 virus can be transmitted to and from the surrounding community through the movement of personnel and guests, inmates' visitors, as well as the admission, transfer and release of inmates [5]. In addition, there is a high prevalence of noncommunicable chronic diseases among inmates, which increases the risk of the severe course of the disease caused by the SARS-CoV-2 virus (COVID-19), and makes early detection of the infection important $[6,7]$. 
The objectives of the study are: (1) to present the number and percentage of officers and employees of the Prison Service (PS), and inmates quarantined and infected with SARSCoV-2 virus in the period from 1 March - 31 December 2020, and (2) to present prevention measures for SARS-CoV-2 virus transmission among PS officers, employees and inmates.

\section{MATERIALS AND METHOD}

The epidemic situation in penitentiary establishments was analysed in the period from the introduction of the first solutions aimed at combating the epidemic caused by the SARS-CoV-2 virus in penitentiary establishments, i.e. from March to the end of December 2020. Information on the number of PS officers and employees, as well as inmates quarantined, and laboratory-confirmed cases of SARS-CoV-2 infections was obtained from the Ministry of Justice pursuant to the provisions of the Act on access to public information [8]. People exposed to the disease caused by the SARS-CoV-2 virus (COVID-19) or in contact with a source of biological pathogens causing it were quarantined [9]. A positive result in the RT-PCR test for SARS-CoV-2 infection was considered a laboratory-confirmed case. In Poland, laboratory testing for SARS-CoV-2 in suspected cases is based on the detection of unique sequences of SARS-COV-2 virus RNA by real-time reverse-transcription polymerase chain reaction (RT-PCR). Laboratory testing of suspected cases is organized in line with the World Health Organization (WHO) guidelines [10].

Detailed solutions implemented in this period in penitentiary establishments, aimed at limiting the transmission of infections among PS officers and employees, and inmates, are also presented. Solutions introduced by the legislator in the applicable provisions of the law, as well as solutions introduced by the Prison Service Management Board, were identified and presented. Legal Acts adopted in the period from March to the end of December 2020 were analysed in terms of introducing solutions limiting the transmission of the virus in penitentiary establishments. Legal provisions in this regard were introduced in the socalled Crisis Act. Information on the solutions introduced by the Management Board of the Prison Service was obtained from the Ministry of Justice under the provisions of the Act on Access to Public Information.

\section{RESULTS}

Data on the number and percentage of PS officers, employees and inmates quarantined and infected with SARS-CoV-2 are presented in Table 1.

From 1 March 2020 - 31 December 2020, the number of cases of SARS-CoV-2 infections detected among PS officers and employees was 3,666, and among inmates - 599. The first case of infection with the SARS-CoV-2 virus was recorded on 24 March 2020. During this period, two PS officers infected with the SARS-CoV-2 virus died. There have been no reported deaths among inmates due to the SARS-CoV-2 virus. Since October, the number of infected people and people quarantined has increased significantly (both in the group of PS officers and employees, and among inmates). $97.7 \%$ of all cases of SARS-CoV-2 infections and $81 \%$ of quarantine referrals among PS officers and employees, and 93.8\% of cases of infections with SARS-CoV-2 and 57.8\% of quarantine referrals among inmates were reported in the last three months of the year. In October, the number of PS officers and employees undergoing quarantine (compared to September) increased more than eightfold. In the group of inmates, this increase was almost twofold).

The study presents the dynamics of the number of cases infected with SARS-CoV-2 virus (Fig. 1) as well as the dynamics of the number of persons quarantined (Fig. 2) among PS officers, employees and inmates in the period March - December 2020.

The study also presents solutions to reduce the transmission of the SARSCoV-2 virus among PS officers, employeesand

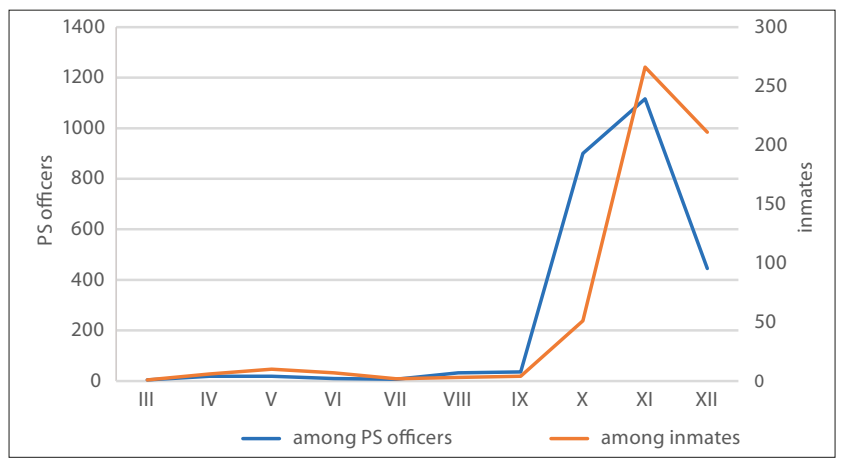

Figure 1. Dynamics of the increase in the number of new infections among PS officers, employees and inmates

Table 1. Number of new infections and quarantine referrals among PS officers, employees, and inmates

\begin{tabular}{|c|c|c|c|c|c|c|c|c|c|c|}
\hline \multirow{3}{*}{ Month } & \multicolumn{5}{|c|}{ PS officers and employees } & \multicolumn{5}{|c|}{ Inmates } \\
\hline & \multicolumn{2}{|c|}{ Infected } & \multicolumn{2}{|c|}{ Quarantined } & \multirow{2}{*}{ total } & \multicolumn{2}{|c|}{ Infected } & \multicolumn{2}{|c|}{ Quarantined } & \multirow{2}{*}{ total } \\
\hline & $\mathrm{n}$ & $\%$ & $\mathrm{n}$ & $\%$ & & $\mathrm{n}$ & $\%$ & $\mathrm{n}$ & $\%$ & \\
\hline March & 4 & 0.01 & 217 & 0.77 & 28,077 & 4 & 0.005 & 175 & 0.24 & 74,035 \\
\hline April & 10 & 0.03 & 317 & 1.09 & 29,024 & 6 & 0.008 & 211 & 0.30 & 71,470 \\
\hline May & 4 & 0.01 & 91 & 0.31 & 28,895 & 7 & 0.010 & 188 & 0.27 & 70,251 \\
\hline July & 5 & 0.02 & 103 & 0.36 & 28,812 & 3 & 0.004 & 121 & 0.17 & 69,285 \\
\hline August & 24 & 0.08 & 202 & 0.70 & 28,758 & 3 & 0.004 & 137 & 0.20 & 68,741 \\
\hline September & 28 & 0.10 & 305 & 1.05 & 28,958 & 9 & 0.013 & 341 & 0.49 & 69,065 \\
\hline October & 1,045 & 3.59 & 2,556 & 8.78 & 29,122 & 53 & 0.077 & 635 & 0.93 & 68,518 \\
\hline November & 1,814 & 6.23 & 2,249 & 7.73 & 29,097 & 284 & 0.417 & 670 & 0.98 & 68,180 \\
\hline
\end{tabular}




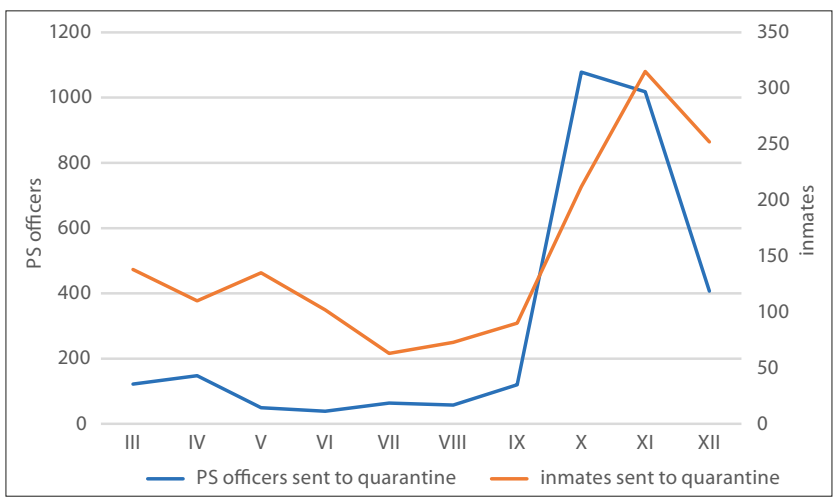

Figure 2. Dynamics of the increase in the number of PS officers, employees and inmates quarantined

inmates implemented in Poland from March to the end of December 2020.

Solutions that can be used when it is necessary to reduce the risk of an epidemic in a penitentiary establishment were introduced by the legislator in the so-called Crisis Act [3]. The penitentiary court, upon request of the director of a penitentiary establishment, may grant a prisoner a suspension in the execution of the prison sentence. If the prisoner cannot be granted a suspension in the execution of the prison sentence, and it is not possible to limit or eliminate the risk of the prisoner infecting another person as part of actions taken in a given establishment, the director of the penitentiary establishment may submit an application to the penitentiary court, approved by the Director General of the Prison Service, for the execution of the sentence in the form of placing the convict in an appropriate treatment institution. A session of the penitentiary court may be held with the use of technical devices enabling this activity to be performed remotely with the simultaneous direct audiovideo transmission. The Act also extended the possibility of executing the prison sentence in the Electronic Supervision System (ESS). A rule was also introduced according to which an officer of the Prison Service may remain on duty for no longer than 24 hours, followed by at least 48 hours off-duty. In addition, special procedures were introduced by the Prison Service Management Board (Tab. 2). These procedures were developed taking into account the applicable legal regulations and guidelines of the Chief Sanitary Inspector.

Table 2. Prevention measures for SARS-CoV-2 transmission among PS officers, employees, and inmates

Action Introduced on Detailed solutions

Algorithms for dealing with suspected infection or infection with SARS-CoV-2 virus were developed. Directors of penitentiary establishments were obliged to establish Epidemic Prevention Teams which, among others, conduct epidemiological inquiries. Based on the findings of these teams, decisions were made regarding possible quarantine or isolation. It was established that prisoners were to be quarantined in specially designated rooms in penitentiary establishments, and isolated in established isolatories. Isolatories were prepared in two prison hospitals, namely, the hospital in the Correctional Facility in Potulice and the hospital in the Remand Centre in Bytom. These were inmates infected with the SARS-CoV-2 virus but regarding whom the doctor stated that there are no indications for hospitalization. Persons in custody infected with the SARS-CoV-2 virus requiring hospitalization were transported by Medical Rescue Teams to non-prison hospitals providing health services to infected patients.

Officers and employees of the Prison Service were obliged to use disinfectants and personal protective equipment when performing their official tasks. Officers were required to measure body temperature of each person entering penitentiary establishments.

A decision was made to equip inmates, including those leaving penitentiary establishments, with disinfectants and personal protective equipment. It was recommended to increase inmates' access to running hot water and to increase the number of baths.

Appointment of a team for coordination of actions taken in connection with the epidemiological hazard in organizational units of the Prison Service by the Director General of the Prison Service

A decision was made to carry out risk assessment in penitentiary establishments in order to identify those most vulnerable within the prison population. A decision was made to place all persons admitted to penitentiary establishments for temporary purposes under observation for a period of 14 days to minimize contact with other inmates, as well as officers and employees of the Prison Service.

A daily review of the epidemiological situation in penitentiary establishments was introduced in the form of video conferences of the management of the Prison Service, district directors of the Prison Service and commanders of training centres of the Prison Service.

A decision was made to conduct a continuous information campaign on the SARS-CoV-2 virus threat for inmates. In addition, officers of the Prison Service were obliged to intensively monitor the atmosphere among inmates and their reactions to emerging information about the epidemic threat.

Suspension of visits was recommended. At the same time, access to telephones was increased, the time of telephone conversations was extended, and the possibilities of using Internet communicators were increased.

External employment of inmates as well as religious services were suspended. It was recommended to limit the movement of inmates around premises as much as possible.

It was recommended to limit to the necessary minimum group cultural, educational, sports and therapeutic activities. At the same time, it was recommended to increase the possibility of using radio and television by inmates by extending the time of access to electricity, increasing the limits of books and newspapers borrowed.

Classes in Continuing Education Centres (CKU) were suspended. At the same time, taking into account the possibilities of penitentiary establishments, it was recommended to teach CKU students by delivering tasks, materials and textbooks prepared by teachers and approved by the director of a given establishment, directly to cells.

Directors of penitentiary establishments were provided with recommendations on how to carry out walks.

Recommendations of the Deputy Director General of 2 April the Prison Service
It was recommended to limit transport activities to the necessary minimum. The restrictions were also to apply to transport activities carried out as part of weekly nationwide transport, as well as transport activities carried out at the request of external authorities, e.g. courts and prosecutor's offices. 
Table 2. Prevention measures for SARS-CoV-2 transmission among PS officers, employees, and inmates (continuation)

\begin{tabular}{|c|c|c|}
\hline \multirow{2}{*}{$\begin{array}{l}\text { Recommendations of the } \\
\text { Director General of the } \\
\text { Prison Service }\end{array}$} & \multirow[t]{2}{*}{1 July } & $\begin{array}{l}\text { The possibility of performing work in rooms and production halls located on the premises of penitentiary units and in their } \\
\text { immediate vicinity, in prison work establishments and in organizational units of the Prison Service was restored. }\end{array}$ \\
\hline & & The possibility of organizing EU-funded training for inmates was restored. \\
\hline $\begin{array}{l}\text { Recommendations of the } \\
\text { Director General of the } \\
\text { Prison Service }\end{array}$ & 1 August & $\begin{array}{l}\text { Visits of inmates' family members and close friends were restored and the rules for visits established. One adult may participate } \\
\text { in visits with an inmate. Visits last } 60 \text { minutes and scheduled as follows: one visit per month per inmate. During visits, physical } \\
\text { contact between the inmate and the visitor is forbidden. Both visitors and inmates are required to wear protective masks } \\
\text { and gloves. The obligatory temperature measurement of visitors and inmates is performed. In addition, the designated } \\
\text { communication routes for visitors and inmates must not cross. Each table should be separated by a partition enabling eye } \\
\text { contact, and visiting rooms are equipped with disinfectants. }\end{array}$ \\
\hline
\end{tabular}

Recommendations of the

Director General of the $\quad 17$ August Group cultural and educational activities, as well as sports and therapeutic activities, were restored under the sanitary regime. Prison Service Classes in Continuing Education Centres (CKU) were resumed.

Recommendations of the

Director General of the 8 September Religious services in the sanitary regime were restored (individual meetings, broadcasts of holy masses via radio and television). Prison Service

The possibility of performing work outside the premises of penitentiary establishments was restored. Work could be performed for State Treasury companies; in food industry companies; in places where convicts perform work in the open; in enterprises implementing contracts in connection with the received grant or loan from the Fund for the Vocational Activation of Inmates. It was recommended that the employer should equip inmates with protective masks and disposable gloves for moving to and from the workplace. Transport of convicts to the workplace and to penitentiary establishments is to be carried out by means of transport properly prepared and organized by the employer. A rule was introduced to minimize contacts between inmates and other employees of a given enterprise. Officers of the Prison Service inspect places of employment in terms of providing personal protective equipment, hygiene and sanitary conditions and disinfectants. Convicts employed outside the premises of a penitentiary establishment are deployed taking into account the workplace criterion, if possible in separate cells, residential wards, and also separately from other convicts.

Visits were suspended and the work of convicts outside penitentiary establishments limited.

Transport activities limited to the necessary minimum; in the case of transport, the activities were carried out in compliance with the sanitary regime, i.e. temperature measurement, obligation to cover the nose and mouth, there were also restrictions on the number of seats occupied to $50 \%$ in convoy vehicles.

Recommendations of the Director General of the Prison Service
24 Octob er

Group cultural, educational, sports and therapeutic activities limited to the necessary minimum (activities are organized in small groups or as part of cells). Depending on the epidemic situation, the method of conducting educational classes at CKUs was established. Learning conducted in the following forms: stationary - in accordance with the rules of the sanitary regime, hybrid or remote forms.

Movement of inmates around the premises of penitentiary establishments was limited.

\section{DISCUSSION}

In Poland, two waves of SARS-CoV-2 infections were recorded in 2020. During the first wave (March-June), the highest number of laboratory-confirmed cases was recorded on 8 June 2020 (599). In the last days of September 2020, the number of infections increased significantly. In the peak of the second wave, on 7 November 2020, 27,875 infections with the SARS-CoV-2 virus were recorded [11]. In the period from March - 30 September 2020, isolated cases of infection with the SARS-CoV-2 virus were found among inmates. The number of new infections in these months did not exceed 10 people and ranged from $0.005 \%$ in March to $0.013 \%$ in September. During that period, the number of new infections among PS officers and employees was also small, ranging from $0.01 \%$ in March to $0.10 \%$ in September. Here, it is worth highlighting that it would be interesting to compare the number of SARS-CoV-2 infections among representatives of the various uniformed services. In Poland, research on infections has been conducted among police officers and its results have been published. In Poland, the police are an example of a uniformed service that was also actively involved in combating the COVID-19 pandemic, they were tasked, inter alia, with the daily monitoring of people in quarantine or selfisolation. The cross-sectional SARS-CoV-2 screening survey performed among 5,082 police employees in Poland showed that the anti-SARS-CoV-2 IgG was positive in over $4.3 \%$ of participants, which suggests a past SARS-CoV-2 infection [12].
It can be assumed that the low number of infections among inmates of penitentiaries as well as PS officers and employees results from the introduction and strict implementation of procedures aimed at reducing the number of infections. Importantly, the vast majority of these procedures were introduced before the first case of infection in these groups was reported. Proper monitoring of the epidemiological situation in penitentiary establishments and making decisions as to possible quarantine or isolation were also important. It cannot be ruled out that the number of infections among inmates and PS officers and employees was higher, especially since no screening tests were carried out in these groups. Nevertheless, the lack of massive numbers of infections justified the decision on the lack of screening. A favourable epidemiological situation in penitentiary establishments justified the fact that in the period from 1 July - 14 September 2020 , restrictions and prohibitions previously introduced by the Prison Service Management Board were lifted.

It is also worth noting that the epidemiological situation in penitentiary establishments in Poland seems to be much more favourable than in many other countries, which is confirmed by data published in scientific papers. For example, in France, as of 23 April 2020, 0.14\% ( $\mathrm{n}=267)$ of infected inmates and 267 officers were reported (no data on the total number of employees) [13]. In turn, in the USA, as of 4 May, 1,926 cases $(1.3 \%)$ and 38 deaths among inmates and 350 cases of infection among employees [14] (9.7\%) were confirmed in federal prisons. By 6 June, 3.2\% of infections and 1.2\% 
of deaths among inmates [15] were reported. In Brazil, 531 infections and 22 deaths were reported by 11 May 2020; by 14 August, the number rose to 465, with the infection rate in State prisons at 2.6\% [16].

In Poland, a higher percentage of SARS-CoV-2 infections was found among PS officers and employees than among inmates. It cannot be ruled out that people employed in penitentiary establishments moving from these establishments to the surrounding community were more exposed to the risk of infection with SARS-CoV-2 virus. This may explain the higher percentage of infections among PS officers and employees.

It was found that in the period from October 2020, the number of infected people and people quarantined increased significantly (both in the group of PS officers, employees and among inmates). A similar tendency was noticeable across the entire country. Infections among PS officers and employees as well as inmates seem to be parallel to the epidemiological situation in the population of the entire country - with the increase in the number of infections in the population and the development of the second wave, the number of infections in penitentiary establishments also increased. A different tendency was observed, for example, in Brazil. Analysis of infection trends in the period from 11 May - 14 August 2020 for the entire country and its macro-regions showed that, although there was a downward trend, in the same period there was an upward trend in prisons [16]. In December 2020, a significant decrease in quarantine referrals and infections was recorded in Poland among PS officers and employees, and a not so clear decrease - among inmates. It cannot be ruled out that this was the beginning of a trend reversal, most likely resulting from the restoration of some restrictions. Further analysis of the epidemic situation will confirm the impact of the organizational measures taken on the incidence of COVID-19 among PS officer, employees and inmates in penitentiary establishments.

The presented study also shows the organizational solutions introduced to reduce the transmission of the SARSCoV-2 virus among officers and employees of the Prison Service and inmates, which were implemented in Poland from March to the end of December 2020. These solutions were implemented in two ways. Firstly, in the applicable legal regulations. Secondly, as part of decisions and recommendations issued by the PS Management Board. Introducing solutions by PS management should constitute the dominant form. As opposed to introducing changes in the law, issuing decisions by the PS Management Board seems to be a faster form of reaction to the changing epidemiological situation. The solutions introduced in penitentiary establishments partially overlap with those introduced in other countries. In France, for example, inmates were released from imprisonment (over 10,000 inmates were released, most of them with a remaining sentence of less than six months) which was replaced with house arrest [17]. On the other hand, in Italy all penitentiary employees in areas with a high number of infections were dismissed from service, and the transfer of inmates to other prisons was suspended. A crisis unit was established to constantly monitor infections and make decisions in the event of suspicion or confirmation of SARS$\mathrm{CoV}-2$ virus infections. As the introduced solutions did not bring the result in the form of reducing the number of infections, further restrictions were introduced. Medical procedures requiring contact with the outside community were suspended. People visiting inmates and lawyers were obliged to use personal protective equipment. The work of inmates inside and outside penitentiary establishments was restricted. Personal visits were replaced by contact by phone or online. Judiciary bodies were encouraged to grant and extend leaves already granted for good conduct. Moreover, it was possible to serve sentences of less than 18 months under house arrest [18]. In the USA, testing and potential treatment were considered the most important activities. It was recommended to release inmates and reduce the number of admissions to prisons, and to replace prison sentences with alternative methods. Other measures put in place included social distancing, improving sanitary conditions, providing sanitary protection measures, and designating space for isolation [19].

Information on activities aimed at limiting the transmission of the SARS-CoV-2 virus in penitentiary establishments and their impact on the epidemiological situation may be used as a tool to control the epidemiological situation in penitentiary establishments in the future, if necessary and also to develop a universal model of anti-epidemic measures, the introduction of which could be recommended as regards to the prevention of outbreaks of highly contagious diseases in penitentiary establishments. COVID -19 represents a unique challenge to penitentiary establishments due to its specific epidemiology; hence, every piece of information on measures being undertaken are of the utmost importance for further evaluation.

\section{CONCLUSIONS}

1. The rapid introduction of solutions aimed at limiting the transmission of the SARS-CoV-2 virus and proper monitoring of the epidemic situation in penitentiary establishments resulted in a low number of infections in the period from March to the end of December 2020.

2. Infections among PS officers and employees as well as inmates seem to be parallel to the epidemiological situation in the population of the entire country - with the increase in the number of infections in the population and the development of the second wave, the number of infections in penitentiary establishments also increased.

3. Further analysis of the epidemic situation will confirm the impact of the measures taken on the incidence of COVID-19 among PS officers and employees, and inmates in penitentiary establishments.

4. Considering the specificity of penitentiary establishments, the legislator in the applicable law and the PS Management Board in the decisions and recommendations introduced a number of regulations limiting the transmission of the SARS-CoV-2 virus.

\section{REFERENCES}

1. World Health Organization. Statement on the second meeting of the International Health Regulations (2005) Emergency Committee regarding the outbreak of novel coronavirus (2019-nCoV). Geneva, Switzerland, January 30, 2020; https:/www.who.int/news-room/ detail/30-01-2020-statementon-the-second-meeting-of-theinternational-health-regulations-(2005)-emergency-committee regarding-the-outbreak-of-novel-coronavirus-(2019-ncov); access: 17 December 2020. 
2. Act of December 5, 2008 on preventing and combating infections and infectious diseases in humans (Journal of Laws of 2020, item 1845, as amended). This act was amended seven times in the period from January 9 to November 30, 2020; https://isap.sejm.gov.pl/isap.nsf/DocDetails. xsp?id=WDU20082341570; access 15 December 2020.

3. Act of March 2, 2020 on specific solutions related to the preventing, counteracting and combating COVID-19, other infectious diseases and the crisis situations caused by them (Journal of Laws of 2020, item 374, as amended); https://isap.sejm.gov.pl/isap.nsf/DocDetails. xsp?id=WDU20200000374; access 15 December 2020.

4. Hagan LM, Williams SP, Spaulding AC, Toblin RL, Figlenski J, Ocampo J, Ross T, et. al. Mass Testing for SARS-CoV-2 in 16 Prisons and Jails - Six Jurisdictions, United States, April-May 2020, MMWR Morb Mortal Wkly Rep. 2020; 69: 1139-1143.

5. Wallace M, Marlow M, Simonson S, et al. Public health response to COVID-19 cases in correctional and detention facilities-Louisiana March-April 2020. MMWR Morb Mortal Wkly Rep. 2020; 69: 594-598.

6. Hawks L, Woolhandler S, McCormick D. COVID-19 in prisons and jails in the United States. JAMA Intern Med. 2020; 180: 1041-1042.

7. Maruschak LM, Berzofsky M, Unangst J. Medical problems of state and federal prisoners and jail inmates, 2011-12. Washington, DC: Department of Justice, Bureau of Justice Statistics; 2015. https://www. bjs.gov/content/pub/pdf/mpsfpji1112.pdf; access 20 January 2021.

8. Act of September 6, 2001 on access to public information (Journal of Laws of 2019, item 1429); http://isap.sejm.gov.pl/isap.nsf/DocDetails. xsp?id=wdu20011121198; access: 17 December 2020.

9. Regulation of the Minister of Health of 6 April 2020 on infectious diseases resulting in the obligation of hospitalization, isolation or isolation at home, and the obligation of quarantine or epidemiological supervision (Journal of Laws of 2020, item 607).

10. World Health Organization (WHO). Global surveillance for human infection with coronavirus disease (COVID-19), Interim guidance as of February 27, 2020. https://www.who.int/publications-detail/ global-surveillance-for-human-infection-with-novel-coronavirus(2019-ncov); access December 19, 2020.
11. https://www.gov.pl/web/koronawirus/wykaz-zarazen-koronawirusemsars-cov-2; access 18 December 2020.

12. Gujski M, Jankowski M, Pinkas J, Wierzba W, Samel-Kowalik P, Zaczyński A, Jędrusik P, Pańkowski I, Juszczyk G, Rakocy K, Raciborski F. Prevalence of Current and Past SARS-CoV-2 Infections among Police Employees in Poland, June-July 2020. J Clin Med. 2020; 9(10): 3245. doi:10.3390/jcm9103245.

13. 2020. COVID-19 en prison: des mesures gouvernementales insuffisantes. Site Contrôleur Général Lieux Priv Lib. https://www.cglpl.fr/2020/ covid-19-en-prison-des-mesures-gouvernementales-insuffisantes; access 28 April 2020.

14. 2020. BOP: COVID-19 update. https://www.bop.gov/coronavirus; access 28 April 2020.

15. Saloner B, Parish K, Ward JA, DiLaura G, Dolovich S. COVID-19 Cases and Deaths in Federal and State Prisons. JAMA. 2020; 324(6): 602-603.

16. Crispim JA, Ramos ACV, Berra TZ, Santos MSD, Santos FLD, Alves LS, Costa FBPD, Arcêncio RA. Impact and trend of COVID-19 in the Brazilian prison system: an ecological study. Cien Saude Colet. 2021; 26(1): 169-178.

17. Fovet T, Lancelevée C, Eck M, Scouflaire T, Bécache E, Dandelot D, Giravalli P, Guillard A, Horrach P, Lacambre M, Lefebvre T, Moncany AH, Touitou D, David M, Thomas P. Prisons confinées: quelles conséquences pour les soins psychiatriques et la santé mentale des personnes détenues en France? [Mental health care in French correctional facilities during the Covid-19 pandemic]. Encephale. 2020; 46(3S): 60-65.

18. Cingolani M, Caraceni L, Cannovo N, Fedeli P. The COVID-19 Epidemic and the Prison System in Italy. J Correct Health Care. 2020 Jul 6: 1078345820929733. doi: 10.1177/1078345820929733. Epub ahead of print. PMID: 32627645.

19. Montoya-Barthelemy AG, Lee CD, Cundiff DR, Smith EB. COVID-19 and the Correctional Environment: The American Prison as a Focal Point for Public Health. Am J Prev Med. 2020; 58(6): 888-891. 